Abstract P170 Table 1 Histology for 1350 patients with lung cancer diagnosed at a London hospital between 2000 and 2011

\begin{tabular}{|c|c|c|c|c|c|c|c|c|c|c|}
\hline & $\begin{array}{l}\text { squamous cell } \\
\text { carcinoma }\end{array}$ & & adenocarcinoma & & $\begin{array}{l}\text { small cell } \\
\text { tumour }\end{array}$ & & $\begin{array}{l}\text { probable cancer-unconfirmed } \\
\text { histologically }\end{array}$ & & Total $\mathbf{n}$ & Total \% \\
\hline & $\mathbf{n}$ & $\%$ & $\mathbf{n}$ & $\%$ & $\mathbf{n}$ & $\%$ & $\mathbf{n}$ & $\%$ & & \\
\hline 2000-2001 & 94 & $47 \%$ & 42 & $21 \%$ & 24 & $12 \%$ & 38 & $19 \%$ & 198 & $100 \%$ \\
\hline 2002-2003 & 88 & $38 \%$ & 46 & $20 \%$ & 35 & $15 \%$ & 60 & $26 \%$ & 229 & $100 \%$ \\
\hline 2004-2005 & 76 & $33 \%$ & 52 & $23 \%$ & 34 & $15 \%$ & 67 & $29 \%$ & 229 & $100 \%$ \\
\hline $2006-2007$ & 82 & $38 \%$ & 64 & $29 \%$ & 26 & $12 \%$ & 45 & $21 \%$ & 217 & $100 \%$ \\
\hline 2008-2009 & 75 & $32 \%$ & 89 & $38 \%$ & 20 & $9 \%$ & 48 & $21 \%$ & 232 & $100 \%$ \\
\hline 2010-2011 & 59 & $24 \%$ & 111 & $45 \%$ & 26 & $11 \%$ & 49 & $20 \%$ & 245 & $100 \%$ \\
\hline Total & 474 & $35 \%$ & 404 & $30 \%$ & 165 & $12 \%$ & 307 & $23 \%$ & 1350 & $100 \%$ \\
\hline
\end{tabular}

Chi-square $\mathrm{P}<0.001$

probable lung cancer unknown histology, first seen between January $1^{\text {st }} 2000$ and January $1^{\text {st }} 2012$. We analysed age, sex, histological cell type, stage and performance status by epoch. The results were tabulated and examined visually and using the chi-square test. Age was examined using one-way Anova. We used SPSS for MAC V19.

Results One thousand three hundred and fifty patients met the entry criteria. Variables were distributed as follows; 839 men (62\%), median age 71 years (inter quartile range 61-78), squamous cell 474 (35\%), adenocarcinoma 404(30\%), small cell (12\%), probable cancer unconfirmed histologically $307(23 \%)$. early stage 234 (17\%), locally advanced $366(27 \%)$, advanced 620 (46\%), not staged $130(10 \%)$. Performance status 0-262 (19\%), 1-38829(\%), 2-290 (21\%), 3-213 (16\%), 4-111 (8\%), not staged $86(6 \%)$.

The proportion of patients with squamous cell carcinoma decreased from $47 \%$ to $24 \%$ and the proportion with adenocarcinoma increased from $21 \%$ to $45 \%(p<0.001)$. The proportion of patients with lung cancer who were women rose from 28\% to $44 \%$ $(p=0.02)$. No temporal changes were seen in the other variables.

Discussion There have been dramatic changes in the epidemiology of lung cancer in our hospital over a 12 year period. The significance of these changes for treatment and prognosis should be explored.

1. Devesa SS, Bray F, Vizcaino AP, Parkin DM. International lung cancer trends by histologic type: Male: Female differences diminishing and adenocarcinoma rates rising. International Journal of Cancer 2005; 117(2):294-99.

\section{P171 A RETROSPECTIVE STUDY OF CHANGING PERFORMANCE STATUS AND STAGING IN ALL PATIENTS PRESENTING WITH LUNG CANCER TO THE NORTHERN HEALTH AND SOCIAL CARE TRUST OVER THE PAST DECADE}

doi:10.1136/thoraxjnl-2012-202678.232

AMS McShane, WA Anderson, SMN McNeill, CB Butler, EM Murtagh, JL Leggett, RD Donnelly, JW Weiboldt. Antrim Area Hospital, Northern Health\&Social Care Trust, Antrim, N Ireland

Lung cancer resection rates have become more controversial as the publication of the national lung cancer audit has shown such geographical variation and then national improvement over a small number of years. This could be due to differences in patients, disease, recording of information or real differences in treatment. As well as initiatives to optimise treatments of patients after they present, there have been efforts to encourage patients to present earlier such as the national awareness early diagnosis initative.
Aim To assess if patients presenting with Lung Cancer in the Northern Trust are different in performance status or stage to those presenting a decade ago.

Methods We used previously published data (BTS, Winter 2003) to compare patients from 2001/2002 with patients from 2009/2010 (data collected from the Regional Northern Ireland Cancer Patient Pathway System). The catchment area over this ten year period had increased from 350,000 in 2001 to 450,000 in 2010 as the Causeway hospital has since been included. We compared numbers presenting, patient demographics, performance status at presentation, histology and staging.

Results and Conclusions A total of 563 patients were studied. Allowing for the change in population served by the MDT, similar numbers of patients presented each year with similar demographics. The histology of the groups was also similar however more patients are now being given a histological diagnosis rather than a clinical diagnosis. Our data also showed that patients were presenting at a statistically significant earlier stage of disease for both Small Cell Carcinoma (chi-square, $\mathrm{p}=0.0004$ ) and Non-Small Cell Carcinoma (chi-square, $p=0.01$ ). Patient Performance Status at presentation had statistically improved between 2001 and 2010 (chi-square, $p=0.01$ ). We also found a non-significant trend of higher surgical referral rates in 2010 compared to 2001 . These results may well vary with geography and might be improved by further health promotion in the future.

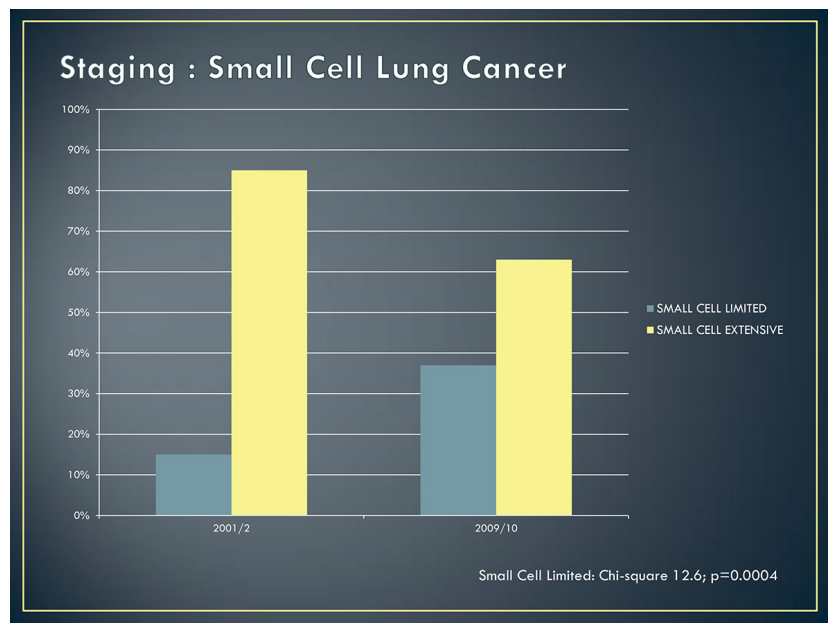

Abstract P171 Figure 1 


\section{Corrections}

AMS McShane, WA Anderson, SMN McNeill, CB Butler, EM Murtagh, JL Leggett, RD Donnelly, JW Weiboldt. P171: A retrospective study of changing performance status and staging in all patients presenting with lung cancer to the northern health and social care trust over the past decade. Thorax 2012;67(Suppl 2):A137. Last author name should be: J Wieboldt.

Thorax 2013;68:162. doi:10.1136/thoraxjnl-2012-202678.232corr1 